\title{
Interpoetyki korespondencji:
}

\section{figury uobecnienia, fikcjonalizacja i zakłócenia technologii obecności}

\author{
Lucyna Marzec
}

\author{
ORCID 0000-0001-6478-3997
}

Dlaczego korespondenci tak często i drobiazgowo informują się wzajemnie o okolicznościach pisania i czytania swoich listów, opisują akt zamykania koperty i naklejania znaczka, wspominają nerwowe oczekiwanie na listonosza, moment wrzucania listu do skrzynki oraz chłonięcia śladów czyjegoś atramentu, całowania koperty, rozpakowywania przesyłki? Dlaczego, używając formuły „kiedy czytać będziesz te słowa...”, zapowiadają i projektują sobie swoją i cudzą przyszłość? Opisują to, jak siebie wyobrażają i jak siebie „słyszą”? Bądź też, przeciwnie, odwołują się do pozaczasowego, pozaprzestrzennego „tu i teraz” wymiany czystych myśli, przekraczającej bariery fizyczne niezmiennej relacji? Zjawisko to ma charakter ponadczasowy i ponadlokalny. W świetle Nowej teorii listu Anity Całek ${ }^{1}$ takie praktyki pisarskie sytuują się w samym centrum refleksji nad listem, ponieważ dotykają kluczowego zagadnienia „listu jako szczególnej formy wypowiedzi, jednocześnie dialogującej i skupionej na nadawcy, który w formie monologu kreuje przestrzeń komunikacyjną, stwarzając w niej siebie i swojego odbiorcę"2. Wiążą się zatem z problematyką autokreacji i autoprezentacji korespondentów oraz relacyjności, interaktywności korespondencji. Przynależą do całego szeregu typowych dla korespondencji strategii uobecnienia, do zestawu podstawowych gestów epistolarnych ${ }^{3}$ i kluczowych figur korespondencji, o czym pisze Esther Milne w monografii Letters, postcards, email. Technologies of presence ${ }^{4}$, a ja charakteryzuję interpoetyckość tych praktyk.

Wydobywa się ona najsilniej w momentach zakłócenia uobecniającej praktyki pisania listu przez innego typu technologię obecności - w XX wieku była to przede wszystkim rozmowa telefoniczna.

\footnotetext{
${ }^{1}$ Anita Całek, Nowa teoria listu (Kraków: Księgarnia Akademicka, 2019).

${ }^{2}$ Całek, 173

${ }^{3}$ Całek, 9, 82, 195-198.

${ }^{4}$ Esther Milne, Letters, Postcards, Email. Technologies of Presence (New York-London: Routledge 2010).
} 
W planie poetyki listu skutkuje to często zaburzeniem narracji skierowanej do osoby nieobecnej, wyobrażonej (wspominanej czy projektowanej) i często łączy się z materialnym śladem - innym kolorem tuszu, zmianą rozmiaru pisma, wprowadzeniem kapitalików. Znaczenie interwencji: dzwonka telefonu, głosu, doznań słuchowych, sytuacji rozmowy, którą się opisuje w pozornie „niemej”, lecz przywołującej pamięć albo wyobrażenie "głosu”, namacalnej korespondencji, warto zestawić z typowymi figurami epistolarnego uobecnienia. List - rozumiany jako medium paradoksalne, transferowe, heterogeniczne, materialne i fantazjujące o swej mocy sprawczej - osiąga punkt szczytowy owej mocy właśnie w praktykach piśmiennego (i nie tylko) uobecnienia adresatki/adresata oraz siebie 5 . Więcej nawet: lwia część korespondencji dotyczy - czy może lepiej opiera się na - właśnie tej fantazji.

Termin interpoetyckość dużo bardziej odpowiada potrzebom konceptualizacji korespondencji niż intertekstualość. Bez względu na to, czy są to listy, karty pocztowe, paczki, bileciki wizytowe, mają niemal zawsze charakter intermedialny (druk i pismo, rysunek i reprodukcja, papier i kartonik etc.), tekstowy i pozatekstowy (piśmienny komunikat i zasuszony kwiatek, dobrany celowo znaczek czy znaczki ułożone w konkretny kształt, samodzielnie wykonana widokówka: kolaż, zdjęcie, wycinek z gazety etc.). Korespondencję nie tylko się czyta, ale także dotyka (całuje, gniecie czy drze), wącha, a nawet smakuje - może angażować wszystkie zmysły, przede wszystkim wzrok i dotyk. Jej foniczność wynika ze skryptoralności każdej wypowiedzi tekstowej ${ }^{6}$, ale jest szczególnie istotna w przypadku, kiedy korespondują ze sobą osoby znające swoje głosy. Korespondencja łatwiej niż literatura daje się uchwycić w momencie, gdy polega na „pisaniu na głos”, gdy znajduje się w stanie dialogu lub półdialogu - zgodnie z tym, jak definiowały praktykę epistolografii dawne teorie listu. Zbliża się tym samym do werbalnej komunikacji opartej na bezpośredniej wymianie zdań, oscyluje między oralnością a piśmiennościąa. Jednak stopień tego zbliżenia nie jest aż tak silny, jak korespondencja obiecuje. Tekstowe/korespondencyjne nigdy nie zastąpi tego, co materialne i oralne.

Zasada ta działa w przeciwnym kierunku: korespondencja jest wyjątkową formą komunikacji. Jednym z konstytutywnych sposobów wytarzania efektu obecności jest fikcjonalizacja, zwłaszcza fikcjonalizacja odbiorcy ${ }^{9}$. Obok materialności właśnie ona ma największy wpływ na budowanie efektu obecności korespondencji. Węzłowy paradoks korespondencji - by odwołać się już tradycyjnie do teorii Stefanii Skwarczyńskiej - polega na tym, że materialność i wirtualność współtworzą ten efekt. Fikcjonalizacja nie polega rzecz jasna na oderwaniu korespondentów od rzeczywistości czy podważeniu referencjalności ich piśmiennych (auto)kreacji, nie jest też sposobem na włączenie epistolografii w twórczość literacką pojmowaną jako twór fikcyjny choć daje taką możliwość ${ }^{10}$. Fikcjonalizacja w korespondencji oznacza wzajemne umieszczenie

\footnotetext{
${ }^{5}$ Por. genezę listu w ujęciu Joanny Correi de Magalhães, cytowanej przez Całek, 9.

${ }^{6}$ Andrzej Hejmej, „W kulturze dźwięku. Słuchanie literatury”, Teksty Drugie 155, nr 5 (2015): 88-102.

${ }^{7}$ Roland Barthes, Przyjemność tekstu, tłum. Ariadna Lewańska (Warszawa: KR 1997), 97-98.

${ }^{8}$ Agata Sikora, List, w Od aforyzmu do zinu. Gatunki twórczości słownej, red. Grzegorz Godlewski, Marta Rakoczy, Paweł Rodak (Warszawa: Wydawnictwa Uniwersytetu Warszawskiego 2014), 247-252; Stefania Skwarczyńska, Teoria listu. Na podstawie lwowskiego pierwodruku opracowała Elżbieta Feliksiak (Białystok: Wydawnictwo Uniwersytetu w Białymstoku 2006), 32-52.

${ }^{3}$ Walter Jackson Ong, „Autor zawsze fikcjonalizuje odbiorcę”, w Osoba, świadomość, komunikacja. Antologia, tłum. J. Japola (Warszawa 2010: Wydawnictwa Uniwersytetu Warszawskiego), 54-8; Józef Japola, „Między retoryką a głosem: Walter J. Ong a problemy komunikacji literackiej”, Pamiętnik Literacki, z. 3 (1997): 152.

${ }^{10}$ Por. rozumienie listu przez Vincenta Kaufmanna, za: Całek, 38-39.
} 
korespondentów w „przestrzeni wirtualnej” stości wykreowanej kulturowo” ${ }^{\text {”2 }}$ czy „drugiej rzeczywistości” ${ }^{13}$, jaką jest każdy dyskurs. Właśnie dlatego przerwanie procesu pisania listu, czyli procesu wytwarzania wirtualnej rzeczywistości telefonem od adresata - a więc zetknięcie $\mathrm{z}$ realnym (choć zniekształconym przez łącza telefoniczne) głosem wywołuje ambiwalentne uczucia korespondentów.

Heterogeniczność korespondencji (a nie tylko listu jako gatunku praktyki piśmiennej, intymistyki/life writing) wiąże się silnie nie tylko $z$ intermedialnością i zróżnicowanymi praktykami dyskursywnymi, z których korzysta, ale także z samej złożonej materialności epistolografii. Myślenie o korespondencji jako medium piśmiennym i tylko piśmiennym (do czego zachęcają edycje listów), redukuje jej znaczenia. Wartość materialnego, wizualnego i piśmiennego aspektu korespondencji jest równorzędna, co wyzyskują do granic twórczynie i twórcy Mail Artu, nurtu w sztuce współczesnej, który wykorzystuje medium przesyłki pocztowej (paczki, listu, kartki) i komunikacyjny charakter poczty jako instytucji ${ }^{14}$. Praktyka przesyłania drogą pocztową pracy artystycznej, której głównym materiałem jest papier pakowy, jako paczki o nieregularnych kształtach (np. ludzkiego ciała) albo namalowanego na płótnie obrazu, w który znaczki wkomponowane są tak, aby tworzyły element figuracji, jest związana $\mathrm{z}$ dwudziestowiecznym ruchem demokratyzacji sztuki, dążeniem do przekraczania granic użytkowości/wysokiego artyzmu, recyklingiem oraz budowaniem społeczności artystów ponad podziałami politycznymi i państwowy$\mathrm{mi}^{15}$. W XXI wieku dodatkowym punktem odniesienia jest globalna sieć internetowa: wirtualna, ale umożliwiająca szybkie nawiązanie kontaktu (call for art works, wymiana adresów pocztowych) oraz podzielenie się fotografią przedstawiającą akt wrzucania do skrzynki pocztowej przesyłki/ kartki (ruch postcrossing ${ }^{16}$ ). Międzynarodowy ruch Mail Art ma jednak swoje wcześniejsze inkarnacje związane z tendencją do „personalizacji” listów i kart przez zwyczajnych użytkowników, obecną już w XIX wieku, kiedy komunikacja pocztowa rozwinęła sieć łączności i staniała na tyle, by korzystały z niej nie tylko najbogatsze warstwy europejskich społeczeństw ${ }^{17}$.

Za interpoetyckością przemawia jeszcze jeden argument: stopniowalna, a czasem płynna, i zamazana granica między użytkowością i literackością listu/kartki, szczególna skłonność listu do tego, by wchłaniać inne media i gatunki (np. opowiadanie, dowcip, anegdotę), aby generować nowe gatunki (np. powieść w listach, list poetycki), a zarazem dostosowywać się do nowych mediów (e-mail, wirtualna kartka pocztowa). Jest to szczególnie widoczne z odległej perspektywy: list zawsze był medium ruchomym - z jednej strony elementem codzienności i wymuszonej odległością komunikacji, z drugiej - częścią piśmiennictwa (np. listy w Biblii, obwieszczenia

\footnotetext{
${ }^{11}$ Joseph Hillis Miller, O literaturze, tłum. Krzysztof Hoffman (Poznań: Wydawnictwo Naukowe UAM).

${ }^{12}$ Całek, 82.

${ }^{13}$ Zob. Całek 99-110 oraz Michael Fleischer, „Podstawy konstruktywistycznej i systemowej teorii kultury”, w Język w komunikacji, t. 1, red. Grażyna Habrajska (Łódź: WSHE2001), 83-104.

${ }^{14}$ Grażyna Bobilewicz, „Poszukiwania form komunikacji - sztuka poczty”. Studia z Filologii Polskiej i Słowiańskiej, t. 41 (2006): 225-237; Piotr Rypson, Mail art., czyli sztuka poczty (Warszawa: Akademia Ruchu 1985).

${ }^{15}$ Ostatnia międzynarodowa wystawa- pośród wielu innych mail artu - miała miejsce w nowojorskim MoMA 1.10-10.12.2012 „Sieć analogowa. Mail art. 1960-1999”, https://www.moma.org/calendar/exhibitions/1482

${ }^{16}$ Zob. https://www.postcrossing.com

${ }^{17}$ Zob. historię zdobionych i „personalizowanych” listów rodziny Tolhurstów, które trafiły do Brytyjskiego Muzeum Poczty, https://postalheritage.wordpress.com/2014/12/04/the-mystery-of-the-tolhurst-envelopes/ i https://postalheritage.wordpress.com/2015/06/29/the-mystery-of-the-tolhurst-envelope-case-closed/
} 
władz), a w końcu i literatury. Podstawowa forma listu - zwrot do osoby, która jest fizycznie nieobecna ${ }^{18}$ - wyzyskana była i jest na różnych polach i obiegach kultury: od Niebezpiecznych związków czy Cierpień młodego Wertera po pocztówkę dźwiękową i rockową balladę PJ Harvey.

\section{Bliskość w załączniku}

Takie zbiory, jak korespondencja Wisławy Szymborskiej i jej partnera Kornela Filipowicza ${ }^{19}$ (związali się w 1967 roku i byli parą do śmierci Filipowicza w 1990) czy Marii Pawlikowskiej-Jasnorzewskiej i jej trzeciego męża Stefana Jerzego Jasnorzewskiego ${ }^{20}$ (byli małżeństwem od 1931 roku do śmierci poetki w 1945) pozwalają z bliska przyjrzeć się intermedialnym i intergatunkowym ruchom listu. Jest to możliwe w ograniczonym zakresie: wydrukowane zbiory korespondencji są pozbawione (w przypadku Szymborskiej i Filipowicza części, w drugim przypadku - całości) materiału ilustracyjnego. Opisy edytorskie, jak np. „wzięte w ramkę” czy „pocztówka z widokiem lotniczym Łodzi, przy słowach «Wszelkie prawa zastrzeżone» dopisek dla "Ciebie»" - pozwala coś niecoś sobie wyobrazić, ale nie zastąpi to kontaktu z listami, kopertami i kartkami. Edytorskie przygotowanie do druku odbiera korespondencji to, co jest dla niej najważniejsze - naznaczoną charakterem pisma sygnaturę osoby ${ }^{21}$. Skan jest też tylko płaskim obrazem, który pozbawia przedmioty ich trójwymiarowości i zmienia ich proporcje. Co więcej, zawartość paczek: żywność, ubrania, pieniądze i inne prezenty, wokół których skupia się często korespondencja, przemijają w czasie, zużywają się. „Odzieranie z materialności” korespondencji wiąże się więc nie tylko z logiką druku i praktyką edytorską, ale z naturą materii i praktyką codzienności - najistotniejszym środowiskiem intymnej korespondencji, w której przesyłki mają pragmatyczny cel, a słowa podtrzymują relację. W obydwu przypadkach załączniki są równorzędnymi elementami piśmiennej wiadomości. Wykraczają poza tekstowe figury uobecnienia i ucieleśnienia ze względu na swą materialność: kiedy Filipowicz przesyła Szymborskiej rodzynki, a Jasnorzewski żonie kawę - to są to realne podarunki, a nie fantazje o prezentach czy wizjach wspólnego obiadu. Nie zastępują fizycznej obecności, tylko wspomagają (ułatwiają, uprzyjemniają) codzienne funkcjonowanie, lecz ich materialność przekracza piśmienną metonimię czy metaforę, zwłaszcza gdy chodzi o brakującą żywność czy odzież.

Trudno przecenić znaczenie paczek, które Maria Pawlikowska-Jasnorzewska i Stefan Jerzy Jasnorzewski przesyłali sobie w czasie ograniczeń aprowizacyjnych podczas II wojny światowej. Oddzieleni niewielką, ale w trakcie wojny sporą, jak na lata 1940-45, odległością kilkudziesięciu mil od Blackpool w Wielkiej Brytanii, gdzie mieszkała poetka, a często zmienianymi bazami lotniczymi, w których stacjonował Jasnorzewski, oficer łącznikowy polskiego lotnictwa, małżonkowie nie

\footnotetext{
${ }^{18}$ Całek 9, Skwarczyńska 50-51, Sikora 247-251.

${ }^{19}$ Wisława Szymborska, Kornel Filipowicz, Najlepiej w życiu ma Twój kot, oprac. T. Fiałkowski, S. Kudas (Kraków: Wydawnictwo Znak, 2016). Dalej Najlepiej i numer strony.

${ }^{20} Z$ Tobq jednym: listy Marii Pawlikowskiej-Jasnorzewskiej i Stefana Jasnorzewskiego, wybór i opracowanie E. Hurnikowa (Warszawa: W.A.B., 2015). Dalej Z Tobq i numer strony. Por. korespondencję zebraną pary: Maria z Kossaków Jasnorzewska, Listy do przyjaciół i korespondencja z mężem (1928-1945), opracował i wydał Kazimierz Olszański (Kraków: Wydawnictwo „Kossakiana”, 1998).

${ }^{21}$ Stąd słowa przeprosin, gdy list pisze się na maszynie, np. z powodu choroby, nieczytelnego pisma czy pośpiechu i tak duża waga, jaką korespondenci przykładają do złożenia podpisu pod listami. Np. niewidoma Kazimiera Iłłakowiczówna posługiwała się pieczątką z faksymile swego podpisu, które składała pod listami dyktowanymi lektorkom.
} 
spotykali się często, ale byli w nieustannym listowym kontakcie. Z całego zbioru tylko kilka listów dotyczy innych spraw niż wzajemna aprowizacja, wieści od rodziny, pomoc finansowa i wsparcie uczuciowe. Są to: kwestie mężowskiej cenzury wojennych wierszy poetki oraz temat postępującej u niej choroby nowotworowej. Tematyka zdrowia/cielesności według Mirelle Bossis, należy do fundamentalnych figur korespondencji ${ }^{22}$. W tym przypadku jednak poetka raczej ukrywała przed mężem swój realny stan, co wiązało się z niedoinformowaniem, tabu schorowanego ciała oraz, jak sugeruje edytorka, odrzuceniem przez Jasnorzewską wiadomości o śmiertelnej chorobie.

Materialność korespondencji Wisławy Szymborskiej i Kornela Filipowicza w mniejszym stopniu związana jest z załącznikami aprowizacyjnymi. Przede wszystkim para przesyłała sobie poglądowe rysunki (zwłaszcza Filipowicz: widoku pokoju, miejsca biwakowania, portret kota), starannie dobrane i znaczące dawne karty pocztowe, które oboje kolekcjonowali. Szymborska do listów wklejała wycinki z gazet i różnego typu drobne przedmioty (np. wstążkę, będącą częścią prezentu imieninowego, przyklejała plastrami), a także obdarowywała Filipowicza autorskimi kolażami -,wyklejankami”23. Trudno zresztą oddzielić kolaże od wielu listów z gazetowymi wycinankami, jeśli myśli się o nich z perspektywy znaczącego medium, ponieważ są one nierozerwalną całością. Na jednym z listów znajduje się np. wklejona ilustracja z łóżkiem, a sam list rozpoczyna się słowami „Kornelu! Nie zamieniaj tego łóźka na dwuosobowe przed moim przyjazdem!” (Najlepiej 161-162). Na innym, podobnie skomponowanym, przy wyciętej z gazety ilustracji kobiecej nogi w pończosze: „To jest moja pierwsza noga, którą wyciągam już w stronę domu. Kiedy prześlę Ci drugą nogę, będzie to znaczyć, że bezapelacyjnie wracam!" (Najlepiej 135-136). Bez ilustracji treść wiadomości pozbawiona jest mieszaniny czułości i absurdalnego humoru, którą wzmacniają - obok hiperboli - zaimki deiktyczne odnoszące się do konkretnych obrazów.

\section{Nonfiction i metafiction korespondencji}

Interpoetyka korespondencji wyraża się nie tylko w łączeniu materialnego i tekstualnego, ale także w epistolarnych grach towarzysko-słownych. W listach Szymborskiej i Filipowicza pojawiają się fikcyjne postacie, które operują własnym krojem pisma, np. popełniający błędy ortograficzne i gramatyczne anonimowi donosiciele przewin i wad partnerów oraz Gienia, uparta rywalka Szymborskiej o uczucia Filipowicza. Najważniejszymi fikcyjnymi postaciami są hrabina Heloiza Lanckorońska i jej plenipotent, Eustachy Pobóg-Tulczyński, przeszłe „wcielenia” pary. Ich rozpisany w czasie dialog, stylizowany na polszczyznę arystokracji początku XX wieku, „opowiada” przygody bawiącej za granicą hrabiny i zdanego na jej kaprysy plenipotenta, odpowiedzialnego za rodowy majątek. Z perspektywy czasu i na drukowanym nośniku ich korespondencję czyta się nie tylko jako wyraz pomysłowości Szymborskiej i Filipowicza, ale „powieść epistolarną w zbiorze korespondencji”, intymne mise en abyme korespondencji osób świadomych kreacyjnej roli pisma, konwencji epistolarnych i literackich. Performatywność listu

\footnotetext{
${ }^{22}$ Mirelle Bossis, Methodological Journeys Through Correspondences, tłum. Karen McPherson, „Yale French Studies”, nr 71 (1986).

${ }^{23}$ „Wyklejanki” noblistki trafiały nie tylko do Filipowicza, ale wielu jej znajomych, stały się tematem opracowań i międzynarodowych wystaw. Zob. Ryszard Matuszewski, Wisławy Szymborskiej dary przyjaźni i dowcipu. Teksty i wyklejanki poetki z kolekcji Ryszarda Matuszewskiego (Warszawa: Oficyna Wydawnicza Auriga, 2008); W. Szymborska, Kolaże/Collages (Kraków: MOCAK, 2014).
} 
łączy się tutaj, nie ściera, z samozwrotnością epistolograficznych konwencji i fikcyjnością: każda wiadomość jest zaproszeniem do kolejnej rundy, którą można, ale nie trzeba, kontynuować.

Fikcjonalizacja jest jednak nie tyle wariantem korespondencji, ile jej koniecznym warunkiem. Przypadek Szymborskiej i Filipowicza tylko wyjaskrawia mechanizm jej działania, ponieważ używa jej w geście metaepistolograficznej gry, świadomej swoich reguł i granic. Ong - a za nim Japola - tłumaczyli konieczną fikcjonalizację odbiorców wszelkich komunikatów, aby wyjaśnić skuteczność działania komunikacji w warunkach, które późniejsi badacze określili „wirtualną rzeczywistością". Polega ona na tym, że podczas pisania listu przywołujemy i zwracamy się nie tylko do realnej osoby, ale jej fikcyjnej persony, rodzaju fantazji, którą mamy na jej temat, wzmacnianej przez pamięć, ale modyfikowanej przez różne czynniki, np. sytuację odległości, długość rozłąki, samopoczucie etc. Fikcjonalizacja wyraża się w budowaniu szczególnego nastroju listu: od formy inicjalnej, która nigdy nie brzmi jak zwyczajne, werbalne powitanie; po sposób, w jaki wyznaczamy adresatowi miejsce w naszym monologu ${ }^{24}$. „Wirtualna rzeczywistość” listu działa podobnie jak każda inna - m.in. literatura, gdy wytwarza sytuacje i finguje stany emocjonalne za pomocą słów. Fikcyjni adresaci korespondencji Szymborskiej i Filipowicza powoływani są do życia nie tylko za pomocą imion, i nie tylko przez stylizacje, ale także poprzez budowanie całego pejzażu emocjonalnego, nieadekwatnego wobec rzeczywistej sytuacji nadawców. Ale i bez stricte fikcyjnych bohaterów korespondencja pary wytwarza „wirtualną rzeczywistość”, w której korespondenci - Szymborska i Filipowicz - są zarówno fizycznie realnymi osobami, które tworzą materialne listy, jak i „wirtualnymi” (Ong powiedziałby: fikcyjnymi) personami, które istnieją jako tekstualne wytwory, a ich geneza jest skomplikowana i heterogeniczna, ponieważ powstaje w wyniku nakładania na siebie i interakcji między autoprezentacją i autokreacją nadawcy i rzutowaniem fantazji na odbiorcę.

Takim samym kodem fikcjonalizacji posługiwali się w korespondencji Szymborska i Zbigniew Herbert ${ }^{25}$. Gdyby usunąć sygnatury autorskie, można by ją przeczytać jako zbiór kuriozalnych listów miłosnych inkrustowanych grafomańskimi wierszami niejakiego Frąckowiaka. Wymiana listów uwidacznia jednak, że adresaci idealnie dopasowywali się do swych ról, wyznaczonych przez nadawców i nie przeszkadzało im to w załatwianiu różnego typu organizacyjnych spraw. Kiedy Herbert przekazywał jeden z takich listów Bibliotece Ossolineum w 1984 roku, dodał w komentarzu, że „nie należy ich odczytywać inaczej niż wyrazy koleżeńskiej sympatii” [Jacyś złośliwi 64]. Uwaga dla postronnych jest być może na wyrost, ale humor oraz ironia bywają kodami tak zakamuflowanymi, że Herbert uznał za konieczne zadbać o czytelność listu. W ten sposób poeta zwrócił się do ustalonego tradycją badania listów „trzeciego odbiorcy” korespondencji - edytora, wydawcy, biografa, a w końcu czytelnika - i uwidocznił wielopoziomowość relacji epistolarnejej - już w pierwotnej „diadzie” między korespondentami poszerzoną o obecność fikcyjnych bohaterów.

Śladów podobnych gier epistolograficzno-literackich można odszukać wiele. Cennym zbiorem jest kolekcja widokówek z pozdrowieniami z Mrzeżyna, które każdego dnia w ciągu trzytygodniowych wakacji w sierpniu 1975 roku Stanisław Barańczak przesyłał przyjacielowi Lechowi

\footnotetext{
${ }^{24}$ Ong 54-85, Japola 152.

${ }^{25}$ Zbigniew Herbert, Wisława Szymborska, Jacyś złośliwi bogowie zakpili z nas okrutnie. Korespondencja 1955-1996, oprac. Ryszard Krynicki (Kraków: a5, 2018). Dalej: Jacyś złośliwi i numer strony.

${ }^{26}$ Całek 199-204.
} 
Dymarskiemu ${ }^{27}$. Strona recto wszystkich widokówek jest taka sama: kolorowa fotografia zachodu słońca nad Bałtykiem. Każda karta napisana jest tak, jakby była pierwszą i jedyną, a ich wspólnym motywem jest wyjaśnienie, dlaczego wcześniejsze wysłanie kartki było niemożliwe. Efekt komiczny wynika z niezborności tych dwóch komunikatów. Ale nie tylko. Wariacje na temat konieczności wysłania pozdrowień znad Bałtyku łączą się z „ćwiczeniami stylistycznymi”, paralelnymi do słynnego zbioru językowych mutacji Raymonda Queneau. Dokonuje się tutaj modyfikacja formy opisu, a także nadawcy i odbiorcy kartki. Mamy do czynienia z podwójnym odbiorcą i podwójnym nadawcą. Metaepistolograficzny kod przeznaczony jest dla realnych osób, które rozpoznają konwencje pisania pocztówek z wakacji. Ich repertuar obejmuje: kartę sprawozdawczą, podniosłą, ustno-potoczną, popisową, telegraficzną etc., wraz z kliszami pocztówkowymi („pogoda śliczna”, „Mrzeżyno - perła polskiego Wybrzeża”, „morze cudne” „wracamy jutro”). Wariacji podlegają typowi nadawcy i odbiorcy pocztówek z wakacji, w których „wciela się” nadawca faktyczny (np. ojca piszącego „za” syna, który pisze „za ojca”, zaradnych harcerek, „życzliwego" donosiciela, niewybrednego żartownisia) i w które obsadza swego odbiorcę (jako druha, „byczego chłopa”, znawcę kultury). Fikcjonalizacja (drugiego stopnia) korespondentów ujawnia się także w apostrofach i podpisach. Znajdziemy tu m.in. takie pary: „Leszku kochany - Twój rozżalony St.”; „Więc Leszku - Barańczakowie”; „Kochany L., cher ami - Stanisław de B. avec sa famille”; czy „Lechu! Chłopie - Stachu z żoną, dołączają się państwo Walczakowie i Fela z mamą i Zdzichem”. Istnienie tak konkretnych tekstowych (fikcyjnych bądź nie) „wcieleń” nadawców i adresatów jest kluczowe dla wywołania efektu obecności. Klisze ożywają w metaepistolograficznej grze poetów-przyjaciół m.in. dlatego, że przylegają do realnych indywiduów. Są niezgodne $z$ ich codziennym sposobem bycia i typowymi formami komunikacji, ale jednocześnie są całkowicie zgodne z charakterystyczną dla poetów tendencją do gier językowych.

Seria pocztówek, które Barańczak przesłał Dymarskiemu, koresponduje z eksperymentem Georges'a Pereca Dwieście czterdzieści dwie pocztówki w prawdziwych kolorach, skierowanym do Itala Calvina ${ }^{28}$. Ta przypadkowa zbieżność wydobywa wspólnotę twórców w podejrzliwości do języka i tendencji do kombinatorycznych gier językowych. Tym razem gra ma tylko literacki charakter, pozbawiona jest warstwy materialnej: pocztówek i pisma, ale też, co istotne, pozdrowienia nie mają konkretyzowanych nadawców i odbiorców. Esej Pereca żongluje kliszami pozdrowień z wakacji, choć tutaj za każdym razem zmienia się lokalizacja (obejmuje letniska i atrakcje turystyczne całego świata). W dużym nagromadzeniu treść widokówek brzmi sztampowo, przewidywalnie: nazwa miejscowości albo hotelu w pierwszym zdaniu, informacje o dacie planowanego powrotu, „ciepłe pozdrowienia” czy „uściski”, informacje o różnych formach wakacyjnego wypoczynku, opalania, jedzonych potraw. Nie ma na pocztówkach z wakacji miejsca na inne treści. Można interpretować tę wariację z powtórzeniami jako ironiczny komentarz: tak właśnie bawi się ludzkość i tak informuje o swoich obyczajach. „Wymowa” widokówek Barańczaka do Dymarskiego jest inna, choć korzysta z podobnego zasobu słownika i umiejętności stylizatorskich: jest wyrazem przywiązania i sympatii. Widokówki z Mrzeżyna to nie tylko gra literacka, każda z nich przekazuje między wierszami

\footnotetext{
${ }^{27}$ Zbiór pocztówek znajduje się w archiwum prywatnym Lecha Dymarskiego. W 2014 roku zbiór był prezentowany na wystawie „Widokówki znad morza i nie tylko” w Wielkopolskim Muzeum Niepodległości w Poznaniu, a w 2015 na Wydziale Filologii Polskiej i Klasycznej UAM.

${ }^{28}$ George Perec, Dwieście czterdzieści dwie pocztówki w prawdziwych kolorach, tłum. Jacek Olczyk, w George Perec, Urodziłem się. Eseje, tłum. Jan Gondowicz, Ewelina Kuniec, Monika Ławniczak, Michał Paweł Markowski, Anna Olczyk, Jacek Olczyk, Tadeusz Pióro, Agata Rębkowska, Ewa Wieleżyńska, Adam Zdrodowski, red. Jacek Olczyk, Kraków: Wydawnictwo Lokator 2012, 119-25.
} 
dodatkową wiadomość: „myślę o tobie codziennie”, a może także: „nudzę się”. W przypadku Pereca istotna jest waga dedykacji - nawet sztucznie spreparowane pocztówki z urlopu poświęca się, ofiarowuje, ale nie wiem, czy będzie pasowało), a więc metaforycznie przesyła, konkretnej osobie.

Korespondencja Jasnorzewskich także opiera się na fikcjonalizacji odbiorcy i nadawcy, wielokrotnie na metapoziomie: korespondują ze sobą świadomi konwencji partnerzy, którzy rozporządzają tekstowymi personami i epistolograficznymi „wcieleniami”. Wiąże się to z rodzinną tradycją Kossaków wymyślania czułych, osobliwych, a czasem cudacznych nazw dla bliskich i dalszych znajomych i rodzaj swoistego rodzinnego idiolektu. Jest ona podtrzymywana przez parę jako znak zażyłości, wytwarza nastrój czułości, tęsknoty, bliskości ich „wirtualnej rzeczywistości”. Kiedy Pawlikowska-Jasnorzewska pisze do męża: „Drogi Loteczku - Ucałowanie od żony (raz i tak można ją nazwać). [...] Robaczkiewicz ty b[ardzo] mój, myśl o Tobie jest pociechą. Mnie rozumiesz Ty" (Z Tobq 115) albo gdy Jasnorzewski pisze do żony: „Szanowna Osobo!” (Z Tobq 130) czy „Dlaczego moja Bajbeczka nie pisze?" ( $Z$ Tobq 150) to sam akt nazywania partnera i siebie, używania trzeciej osoby zamiast pierwszej i drugiej, ma wymiar tyleż performatywny, co właśnie fikcjonalizujący. Kreuje nadawcę i odbiorcę w tym samym stopniu, co wyraża emocje, przy czym istotna jest przemienność imion i przydomków związanych z rolami płciowymi. „Pankiem” bywa tu Jasnorzewska, „Panną Bajbak” - jej mąż, ale praktyka ta ujawnia się wyłącznie w formach inicjalnych. Podpisy są standardowo wariacjami na temat zdrobniałych imion pary, tj. Lilki i Lotka, tak jakby sygnatura listu musiała być gwarancją normy i stałej tożsamości. Mechanizm fikcjonalizacji odbiorcy-nadawcy w korespondencji umożliwia tego typu gry formami inicjalnymi: nie jest do tego konieczna metawiedza. Wystarczy przystanie na reguły „wirtualnej rzeczywistości” korespondencji. Natomiast metaepistolograficzna świadomość pozwala na bezbłędne odczytanie listów-gier.

\section{Intymność na odległość}

Jakkolwiek lektura intymnej korespondencji par wywołuje intensywne doznania czytelnicze ${ }^{29}$, mieszaninę voyeurystycznego wrażenia, że obcuje się z "nagą prawdą” i materiałem „z życia wziętym” oraz nieredukowalnej machiny „narratywizacji” listów na wzór literackich powieści epistolarnych, obydwa zbiory nie generują biografii pary w pigułce, nie dają ekstraktu ze złożonych i wieloletnich relacji, ani nie są utworami literackimi.

Obydwie pary korespondentów: Szymborskiej i Filipowicza oraz Pawlikowskiej-Jasnorzewskiej i Jasnorzewskiego wiązały zażyłe relacje, a okresy korespondencji były marginalne wobec codziennej bliskości, nawet gdy nie oznaczała wspólnego mieszkania (jak w przypadku Szymborskiej i Filipowicza). Fantazje uobecnienia i formy ucieleśnienia korespondenta/korespondentki w ich przypadkach miały silne podstawy - przeszłych doświadczeń i nadziei na szybkie spotkanie. Zgoła odmienne sytuacje analizuje w swojej książce Milne - najczęściej opisuje ona relacje korespondencyjne, które nie miały realizacji w rzeczywistości lub próba realizacji była nieudana (jak romantyczne przyjaźnie epistolarne), albo jej nie mają w tej chwili (jak znajomości na listach mailingowych i forach internetowych). Fizyczne oddalenie - warunek konieczny nawiązania relacji listownej w przypadku analizowanych zbiorów korespondencji ma charakter tymczasowy i wyjątkowy. 
Ze względu na charakter znajomości korespondentów zbiory listów nie są ogromne, proporcjonalnie do okresów oddzielnie spędzonego czasu. Podobnie tematyka listów dotyczy przede wszystkim spraw bieżących, codziennych oraz relacji między parami, służy głównie podtrzymaniu kontaktu i działa przeciw osłabieniu więzi. Z tych samych powodów listy są krótkie. Nie znajdziemy w nich tego, co w listach na stałe oddalonych korespondentów, których znajomość oparta jest przede wszystkim na kontakcie epistolarnym albo tych, którzy nawiązują listowną relację po latach rozłąki: szczegółowych opisów biografii (swojej i bliskich), deklaracji światopoglądowych, wynurzeń intelektualnych, opisów warsztatu i tematów pracy artystycznej etc ${ }^{30}$. W omawianych przypadkach wymieniają się listami, paczkami i widokówkami osoby, które się dobrze znają i nie potrzebują się wzajemnie charakteryzować. Szczegółowo zaś informują się o tym, co różni się w zmienionym (przez wyjazd) otoczeniu i podkreślają niezmienność uczuć. Innymi słowy: listy Szymborskiej i Filipowicza nie przynoszą wiedzy o ich krakowskiej codzienności, zwyczajach, wzajemnych inspiracjach i warsztatach pracy, ale ukazują sposoby podtrzymywania kontaktu w krótkich okresach rozłączenia, opisują warunki tymczasowego zamieszkania i sanatoryjne czy letniskowe zwyczaje, współtowarzyszy i znajomych. Podobnie korespondencja Jasnorzewskich portretuje parę w nadzwyczajnym czasie wojennej rozłąki.

Podkreślam silnie heterogeniczność korespondencji i jej nieredukowalną materialność, ponieważ takie ujęcie wzbogaca rozumienie figur uobecnienia i ucieleśnienia podmiotów dyskursu epistolograficznego. Także charakterystyka intymnej zażyłości obydwu par w ich „pozaepistolarnym" wymiarze jest konieczna, by właściwie ukazać różnice i podobieństwa między moim myśleniem o strategiach uobecniania a propozycją Milne, i by - pomimo wszelkich zastrzeżeń - wykazać, że w najgłębszej warstwie „technologie obecności” działają poza zasadą skuteczności i performatywności oraz na przekór mierzalnym fizycznie realiom.

Korespondencja opiera się na podstawowej wierze, że istnieje adresat, do którego kieruje się swoje słowa, lecz by nawiązać z nim kontakt, konieczna jest fantazja, którą wspierają wszelkie formy zmysłowej i fizycznej bliskości. Wywołują one poczucie niezapośredniczenia, intymności i obecności ${ }^{31}$. Milne w swojej monografii twierdzi, że wszystkie (popularne i wszędobylskie) epistolarne strategie ucieleśnienia działają jednak na rzecz odcieleśnienia korespondentów ${ }^{32}$ : zarówno wysuwanie na plan pierwszy tematyki ciała (które wywołuje efekt bezpośredniości, jak w formule zamykającej list: „Całuję ręce i nóżki kochanej Pani!”), jak i metonimiczne traktowanie materii listu jako ciała korespondenta (co zawiera się w praktyce całowania, wylewania łez, ściskania listów). Im bliżej ciała - tym od niego dalej, twierdzi badaczka. Więcej nawet: prymarną fantazją dyskursu epistolografii jest przekonanie, że komunikacja listowna okazuje się bardziej autentyczna i intymna niż komunikacja twarzą w twarz i daje silniejsze poczucie obecności ${ }^{33}$. Jakkolwiek idea ta zakorzeniona jest w romantycznej wizji niezapośredniczonego spotkania dwojga dusz,

\footnotetext{
${ }^{30}$ Funkcji listopisania, podobnie jak dziennikopisania, można wymienić kilkadziesiąt. W przypadku artystów i ludzi pióra byłaby to przede wszystkim wymiana intelektualna (doradztwo, wyrazy uznania i dezaprobaty, komentarze do utworów, informowanie się o książkach/twórcach/wydarzeniach kulturalnych), załatwianie spraw zawodowych i organizacyjnych (np. wydawniczych, stypendialnych, przekładowych).

${ }^{31}$ Milne, 14: „a sense of immediacy, intimacy and presence”.

${ }^{32}$ Milne, 2, 8-17: „The term disembodiement refers to two distinct but related desires: the desire to escape the corporeal human body and to eclipse the material technology of communication [...] The dream of transcending the corporeal body id informed by the dichotomy of mind/body; while the desire to eclipse or see through a particular technology of communication id underpinned by the binary of information/medium". Milne, 9-13.

${ }^{33}$ Milne, 16.
} 
to jej moc przetrwała zarówno modernistyczne zwątpienia i postmodernistyczne dekonstrukcje podmiotu. Współczesna korespondencja e-mailowa, podobnie jak romantyczne listy, opiera się na podobnych założeniach i pragnieniach wytwarzania intymności, bliskości i relacji - pomimo fizycznej odległości i nieobecności korzysta z podobnych formuł i strategii uobecniania i daje tę samą obietnicę bez pokrycia, że obecność dwojga piszących przyniesie spełnienie fantazji wypracowanych w trakcie korespondencji ${ }^{34}$. Milne przy tym odżegnuje się od hierarchizacji bliskości listownej i bliskości fizycznej. Dla badaczki (ale też Ervinga Goffmana) performatywne gesty tworzenia „siebie” w kontakcie z innymi „na żywo” są porównywalne z praktykami pisemnymi.

Skupiając się na trwałej, wieloletniej korespondencji angielskich romantyków, „nieprzerywanej” zbyt często spotkaniami „na żywo”, wypełnionymi przy tym fantazjami na temat spotkania dusz oraz obcowania ze sobą poprzez materialność listu, Milne niejako wraz z nimi sądzi, że korespondowanie to równoległy wobec fizycznego (materialnego) sposób na znajomość i bliską relację, w takim samym stopniu zagrożoną porażką jak niosącą szansę na sukces i satysfakcję obydwu stron ${ }^{35}$. W istocie wiele długoletnich znajomości epistolarnych, nie tylko epoki romantyzmu, utrzymywało się pomimo (a nawet dzięki) rzadkim spotkaniom w rzeczywistości. A jednak Milne zatrzymuje się w połowie drogi, interpretując przypadki porażek przyjaźni i romansów epistolarnych, podobnie jak pozostawia niedokończoną myśl, iż konieczne dla efektu intymności i obecności w korespondencji jest napięcie pomiędzy realnym, fizycznym ciałem korespondentów a personami, które wytwarzają na użytek korespondowania. Proponuję spojrzeć na tę sprawę inaczej: napięcie rozładowuje się w kontakcie realnym, fizycznym, ponieważ nie pozwala podtrzymać fantazji na temat „ciał korespondentów”, a jako że fantazje te mają najczęściej charakter idealizacji - konsekwencją jest fiasko bliskości „poza listami”. Najczęściej wzmiankowanym przypadkiem w historii kultury są nieudane „romanse listowne” Franza Kafki i Mileny Jesenskiej. Ale równie silnym dowodem są analizowane przeze mnie zbiory korespondencji dwóch par. Figury uobecnienia i ucieleśnienia są w nich bardzo częste oraz intensywne, właśnie dlatego (lub pomimo to), że zasadniczo pary częściej niż epistolarnie obcują ze sobą w rzeczywistości. Fantazje i wizje wiążą się tu nie tyle z trudnymi do realizacji wyobrażeniami, ile z pamięcią (tęsknotą) i realnymi oczekiwaniami. Co więcej, w ich korespondencji zdecydowanie dominuje - nad sprawozdaniem „z życia” i różnymi formami problematyzowania listownego „ja” - właśnie aspekt uobecnienia/ucieleśniania epistolarnego „ty”.

Sam fakt, że poczucie intymności i autentyczności korespondencji opiera się na różnych formach „uobecniania” i „ucieleśniania” korespondentów, świadczy raczej o prymacie fantazji o kontakcie, który daje tylko cielesna, fizyczna bliskość. Rzadko zdarza się, by rozmówcy, spotykający się na żywo, snuli marzenia o korespondowaniu ze sobą. A jednocześnie - właśnie dlatego, że w przypadku znajomości epistolarnych fantazja o kontakcie jest tylko życzeniowa, taka znajomość może się utrzymać pomimo przekroczenia w niej granic przewidzianych przez kulturowy savoir vivre danej epoki. Jej performatywność jest po prostu słaba. Fantazję można (ale nie trzeba) zignorować bez konsekwencji. Widać to na przykładzie korespondencji pisarki Mary Mitford i Williama Elforda, interpretowanych przez Milne ${ }^{36}$. Badaczka szczegółowo opisała ambiwalentne uczucia, które wywołała w pisarce fantazja starszego o czterdzieści lat przyjaciela, jaki dzięki magicznemu talizmanowi transportował

\footnotetext{
${ }^{34}$ Milne, 17.

${ }^{35}$ Milne, 51-90.

${ }^{36}$ Milne, 74-90.
} 
się do jej pokoju i, niewidzialny, obserwował ją: rozmyślającą, czytającą, piszącą. Wieloznaczność marzenia dla Milne jest przede wszystkim dowodem na intymność, którą ci wytworzyli, wbrew „intuicyjnej" interpretacji, która by tłumaczyła, że jest ono sygnałem braku fizycznego kontaktu, tęsknoty za nim ${ }^{37}$. Zgadzam się z Milne, ale rozumiem inaczej przyczyny tego stanu rzeczy: właśnie dlatego, że intymność korespondentów, którzy nie prowadzą równolegle „fizycznej” znajomości, należy do porządku dyskursu, fantazje przelane na papier nie mają mocy silnych aktów performatywnych i nie wpływają znacząco na realne życie korespondentów. Intymność jest bowiem wytwarzana w relacji, a fantazje można snuć w samotności i fizyczna obecność drugiej osoby może je tyleż wzmacniać, co zakłócać i niszczyć. Moc fantazji tkwi między innymi w lekceważeniu elementów, mogących przeszkodzić w jej snuciu. Kiedy Milne cytuje deklaracje użytkowników forum internetowego czerpiących satysfakcję z nawiązanych tam relacji, dlatego że dają one kontakt czysto intelektualny, poza ograniczeniem ciała (m.in. etniczności, koloru skóry, płci), to w moim odczuciu wskazują na te czynniki, które mogą uniemożliwić nawiązanie bliskich relacji (ze względu na dyskryminujące stereotypy). Fora internetowe, grupy dyskusyjne, fandomy, społeczności graczy etc. dają taką możliwość nie tylko ze względu na wytwarzanie technologii obecności, ale także dzięki rudymentarnej machinie fikcjonalizacji nadawcy i odbiorcy w korespondencji i innych „wirtualnych światach”. Fizyczna nieobecność pozwala na dość swobodne fikcjonalizowanie i fantazjowanie. Nie warto jednak bagatelizować zjazdów, konwentów i spotkań wirtualnych grup, a także różnego typu niespodzianek (i porażek) związanych ze spotkaniami na żywo.

Najsilniej świadczą o tym sytuacje graniczne, jak korespondencja pary więźniów politycznych, Zofii i Kazimierza Moczarskich ${ }^{38}$, którzy - przez sześć lat, kiedy oboje przebywali w więzieniu, a łącznie przez dziesięć lat rozłąki - utrzymywali kontakt listowy. Ich listy - pisane w sytuacji granicznej, czytane przez więzienną cenzurę i reglamentowane w zależności od zachowania więźniów - także zawierają formuły uobecniania, przede wszystkim oparte na wspomnieniach. Do pewnego stopnia przypomina to relacje opisywane przez Milne - ale w tym przypadku kontakt bezpośredni był niemożliwy ze względów niezależnych od korespondentów. To świadectwo wstrząsające, choć listy pary pisane $\mathrm{z}$ więzienia są monotonne - powtarzają się te same wspomnienia (zapoznania, ślubu, wakacji) i deklaracje niezmiennego uczucia i siły więzi. Monotonia sugeruje nie tylko hibernację uczuć i wspomnień, ale i cenzorską obecność oraz fizyczne unieruchomienie. Dlatego listy zmieniają się gwałtownie, kiedy Moczarska zostaje zwolniona z więzienia i małżonkowie spotykają się na widzeniach. Konfrontacja wyniszczonych, torturowanych (fizycznie i psychicznie) ludzi, którzy nie widzieli się przez lata - modyfikuje tematykę listów, ale wprowadza inny ton i nastrój, odległy od metafizycznego „porozumienia dusz”. To, że więź udało się podtrzymać i kontynuować po uwolnieniu obojga, jest zjawiskiem wyjątkowym.

Jednak i mniej skrajne sytuacje są znamienne. Listy obydwu par stale podejmują temat spotkań i tęsknoty za niedawną fizyczną obecnością. Jasnorzewski pisze w jednym z listów: „[...] bardzo przykro mi było oddalać się od Panny. W miarę oddalania się żal wzrastał, jak również pewien niepokój, czy Panna była ze mnie rada i zadowolona" (Z Toba 122). Filipowicz do Szymborskiej z biwaku: „[...] po Twoim przedwczesnym wyjeździe bardzo nam tu wszystkim smutno, a najbardziej lokato-

\footnotetext{
${ }^{37}$ Milne, 82-87.

${ }^{38}$ Zofia i Kazimierz Moczarscy, Życie tak nas głupio rozłacza... Listy więzienne 1946-1956, oprac., wstępem i przypisami opatrzyła Anna Machcewicz (Warszawa: Biblioteka „Więzi”, 2015).
} 
rowi z namiotu 4a. W namiocie wszystko zostało po staremu: zajęcza łapka, zepsute lusterko, miętówki, w przedpokoju stoją Twoje czerwone trzewiki - tylko Ciebie nie ma" (Najlepiej 313). Szymborska do Filipowicza: „Kochany Kornelu! Jutro przyjeżdża Adam i dopiero będę miała wiadomości o Tobie. Te trzy dni, w których nie było ani listu ani możności usłyszenia Twojego głosu wydają mi się szczególnie przykre i długie" (Najlepiej 150). Tęsknota za fizyczną obecnością i uczucie lęku związanego z uznaniem spotkania za nieudane, w sytuacji dłuższej rozłąki wiążą się z sytuacją oddalenia. Fantazje wokół porzucenia czy sprawienia zawodu wzmaga brak kontaktu. Oczywiście bardzo trudno orzec, na ile były one obecne w codzienności par, jednak opisy takich stanów pojawią się częściej w korespondencji wtedy, gdy rozłąka zostaje przerwana i pary się na krótko spotykają. Działa tu pewnie przyzwyczajenie do nieobecności - stała cecha relacji czysto epistolarnych czy wirtualnych.

\section{Najczęściej używane figury uobecnienia}

Pomimo zarysowanych różnic pomiędzy korespondencją osób tworzących intymne relacje oparte na obecności oraz relacjach czysto korespondencyjnych, najciekawsze są podobieństwa w wywoływaniu tekstowych „uobecnień”, o których pisze Milne. Pojawiają się one bez względu na „kontekst”, „czas”, „przestrzeń”, stopień zażyłości korespondentów. Oczywiście wszystko to wpływa na kształt wizji, ale nie tłumaczy tego, że figura uobecnienia czy ucieleśnienia w ogóle się pojawia. Określiłabym je toposami i figurami korespondencji. Toposy odnoszą się do stale ponawianych obrazów, tematów i motywów, takich jak: stan zdrowia, warunki bytowe, pogoda, kulinaria. Figury - do konkretnych, powtarzalnych formuł opisujących akt czytania, pisania i wysyłania listu, często związany z wyobrażaniem nadawcy/odbiorcy oraz hipotezami na temat działania poczty.

Praktyki uobecniania polegają na transpozycji pisma w osobę, jak w jednym z listów Kazimiery Iłłakowiczówny do siostry, Barbary Czerwijowskiej: „Takie miłe Twoje literki - jakbyś tu przy mnie była!"39. Przy okazji tematyzowana bywa jakość papieru listownego, koperty, czy wybór ilustracji na pocztówce. Są to materialne ślady (pisma, opuszków palców), ale i świadectwa troski czy uwagi. Figurami obecności są rozbudowane opisy przygotowania do lektury listów, odpieczętowywania pakunków. Szymborska pisze żartobliwie do Filipowicza: „Wiem, że tego listu nie otworzysz natychmiast, tylko dopiero popołudniu, leżąc na tapczanie, z Kizią u boku, po przeczytaniu «Echa» i wysłuchaniu popołudniowych wiadomości w radiu. No i co, zgadłam?" (Najlepiej 387). Maria Pawlikowska-Jasnorzewska szczegółowo opisuje ceremonię otwierania przesyłki od męża:

Mój Robaku przemiły! Paczka przyszła dziś rano. Wniosła ją Ann, siostra Mary, tak rozradowana, jakby to było dla niej. Wzruszająca poczciwość tych dwóch irlandzkich sióstr! Przed otwarciem, które jest zawsze połączone z wyrzutem sumienia, że się psuje pracę zręcznych łapinek pana Robaka, ucałowałam pieczątkę granatową. Widzę, że Bajbaczka mnie lubi, bo tyle sobie zadała trudu, aby ucieszyć. Ucieszyła bardzo (Z Tobq 176).

Granatowa pieczątka jest tu metonimią nadawcy, nawet jeśli całowanie paczki było jedynie fantazją. Ważniejsze jest samo opowiadanie kolejnych faz ceremoniału, związanych ściśle ze

\footnotetext{
${ }^{39}$ Kazimiera Iłłakowiczówna, Listy do siostry Barbary Czerwijowskiej z lat 1946- 1958, oprac. Lucyna Marzec (Poznań: Wydawnictwo Biblioteki Publicznej i Centrum Animacji Kultury, 2014), 257.
} 
zmysłami: najpierw obserwowaniem paczki przyniesionej przez znajomą, a potem rozpakowywaniem - dotykaniem. Finezyjne (a może tylko staranne) opakowanie przesyłki rozumie poetka jako gest troski o nastrój i podtrzymanie sympatii odbiorczyni. Otwarcie paczki - zniszczenie opakowania - jest więcej niż sposobem na dotarcie do zawartości. Opisanie wszystkich towarzyszących odbiorze paczki czynności w zwrotnym liście oznacza „poprawne” odczytanie kodu uczuciowego: czułe słowa za czułe gesty.

W listach Wisławy Szymborskiej do Kornela Filipowicza znajdujemy ten sam szereg. Na przykład w pisanym z sanatorium w 1968 roku (kapitalikami, dla podkreślenia doniosłości komunikatu):

KORNELU! DZIĘKUJĘ ZA ORZECHY I SARDYNKI.

KIEDY OTWORZYŁAM PACZKĘ ZROBIŁO MI SIĘ JAKOŚ CIEP£O. OŚWIADCZAM CI, ŻE TWOJE LISTY I WSZYSTKO CO OD CIEBIE POCHODZI JEST NAPROMIENIOWANE I JA TO ODBIERAM JAKO OTUCHĘ I W OGÓLE WYDAJE MI SIĘ, ŻE JESTEŚ BLISKO. MÓJ KOCHANY (NAJLEPIEJ 105).

Szczegółowo opisane zmysłowe wrażenia związane z otwieraniem paczki są metonimią bliskości fizycznej adresata. Namacalność orzechów i sardynek (nie przez przypadek chodzi o produkty żywieniowe - do fizycznego przyswojenia) odpowiada upragnionej obecności Filipowicza.

Wywoływanie obrazu korespondenta i uruchamianie innych zmysłów (zapachu, dotyku, słuchu) w listownym spotkaniu jest najczęstszą strategią wywoływania efektu obecności w korespondencji. Jej romantyczna wersja przybiera taką formę, jak w liście klasyka romantycznej korespondencji, Zygrnunta Krasińskiego do Konstantego Gaszyńskiego

Gdym czytał Twe słowa wczoraj, ujrzałem Cię nagle przed sobą oczyma serca bladym, zgorzkowanym, zasępionym na licu, a otóż z drugiej strony i w jednejże chwili ujrzałem drugiego Ciebie, młodego, rzeźwego, pełnego ducha i radości, a to Ty był z czasów ery fajkowej i stałem między Wami oboma podając obu Wam ręce i płacząc. A gdy minęło to widzenie, wzniosłem myśl ku Bogu i pomodliłem się o Ciebie, mój drogi, by rozerwanej Twej duszy, żal, tęsknota przemieniły się w siłę twórczą, w zapał odrodzony do pracy umysłowej, w wiarę i ufność, że ten, który ptaka ni lilii polnej nie opuszcza, i nas nie opuści na tym sieroctwie serca i ducha ${ }^{40}$.

A współczesna - znów przykład z listu Wisławy Szymborskiej do Kornela Filipowicza, który wyjechał na ryby z przyjaciółmi:

Kornelu! Myślę o Tobie w różnych porach dnia. Widzę Cię nad wodą, w tym Twoim kapeluszu! [...] Całuję! Przykładam policzek do Twoich pleców! I zupełnie Cię nie zdradzam! Wyobraź to sobie! Wisława (Najlepiej 249).

Obydwie wizje różnią się znacznie - ale pod kilkoma względami są do siebie podobne. Krasiński z rozmachem wyobraża sobie dwóch Gaszyńskich - szczęśliwego, znanego ze wspomnień i obecnego, posuniętego w wieku, zgorzkniałego, a pisze o tym jako widzeniu, fantazji. Punktem odnie- 
sienia w kolejnym zdaniu jest Bóg - źródło wizji religijnych, adresat życzeń o poprawę losu przyjaciela. Ten „wielki nieobecny”, „odbiorca idealny”, do którego pisze się wiersze, modlitwy i listy (oraz wiersze-listy, jak uczynił to np. Barańczak w Widokówkach z tego świata) pozostawia je bez odpowiedzi, co nie udaremnia wysiłków kolejnych pokoleń, by adresować doń listy i wysyłać je (ten temat podejmuje dokument Marcela Łozińskiego Poste restante z 2008 roku o Wydziale Przesyłek Niedoręczalnych Poczty Polskiej). Wydawałoby się, że podejrzliwej wobec wielkich systemów metafizycznych Szymborskiej obce będą wizje bliskości i kontaktu pozazmysłowego, a jednak sposób, w jaki przywołuje obraz Filipowicza, jest podobny do tego, w jaki Krasiński wyobrażał sobie przyjaciela. Wizje różni oczywiście stylistyka - u Krasińskiego dominuje patos, u Szymborskiej - prywatna ironia, humor. Ale i tutaj wprost pisze się o „widzeniu”, wywołanym opisem miejsca biwakowania przez Filipowicza, i kontakcie fizycznym, niemożliwych ze względu na odległość, ale upragnionych. Wyobrażenia i fantazje ciążą ku wizjom ucieleśnienia, zmysłowego kontaktu.

Równie istotne $\mathrm{w}$ wywoływaniu efektu obecności są opisy pisania listów i planów dotyczących ich wysłania - swego rodzaju autokomentarz, który staje się jedynym komunikatem, a więc „niedomiarem” i „nadwyżką” listu jednocześnie. $Z$ listu Jasnorzewskiego do żony: „Skończyłem tamten list o całej historii [...], a teraz parę słów tylko tak. Nie jestem pewien, czy ten list wyślę dziś, bo muszę poszukać odpowiedniej koperty. Ale pewnie pójdzie jutro rano. Tymczasem dodaję dużo serdecznych pocałunków, pozdrowień i uścisków" (Z Tobq 159). Z listu Jasnorzewskiej do męża: „Piszę do Ciebie już w trzy godziny po Twoim odjeździe” (Z Tobq 196). Szymborska do Filipowicza: „Piszę zaraz czyli o 12 w południe, jeszcze przed śniadaniem, ale już po wizycie w antykwariacie” (Najlepiej 15). Filipowicz do Szymborskiej: „Piszę jeszcze dzisiaj przed zapowiedzianym przez Ciebie listem, na który będę mógł odpowiedzieć dopiero jutro wieczorem" (Najlepiej 33). Często wiążą się z prośbami o listy i znakami oczekiwania („Czekam na Twój liścik”, „Pisz do mnie”, „Odpisz, proszę”, „Pisz często”), a także podkreślają okoliczności wysyłania listów. Charakterystyczna jest detaliczność tych opisów, często towarzyszą im deskrypcje warunków pisania listu (lokalizacja w przestrzeni, warunki pogodowe, przede wszystkim czas).

Istotnym punktem odniesienia jest działanie instytucji poczty, zwłaszcza wtedy, gdy nie funkcjonuje płynnie i tak szybko, jak chcieliby tego korespondenci. Pozwala to wydobyć elementarną, obok nieobecności, cechę korespondencji: nieprzystawalność czasu pisania i czasu czytania. Filipowicz do Szymborskiej: „Nad Wieprzem, w okolicy Łysobyków (nazwa nie wymyślona!). Bóg raczy wiedzieć, gdzie i kiedy ta karta zostanie wrzucona do skrzynki" (Najlepiej 26). Szymborska do Filipowicza: „Piszę z Chochołowskiej Dol[iny] i zaraz wrzucę tę karteczkę do skrzynki, która wygląda, jakby z niej wybierali dopiero z końcem roku. Więc może będzie właściwe złożyć Ci najlepsze noworoczne życzenia?" (Najlepiej 219). Konkretne dla nadawcy określenia czasowe, zazwyczaj dotyczące przyszłości („zaraz”, ,jutro”), dezaktualizują się w trakcie przewozu, dla odbiorcy są śladami przeszłości. Dla osoby piszącej list liczy się bowiem „tu i teraz” aktu pisania, w trakcie którego wychylona jest zawsze w stronę przyszłości i epistolarnego ty: „kiedy będziesz czytać te słowa”.

Mistrzem „technologii obecności” był Stefan (Lotek) Jasnorzewski. Pisał w „czwartek, godz. 12.30, 17-18 IV 1942" do żony:

Kochana Panno Bajbas! Niby co to ma być z tym piszczeniem. Kto to miał co dzień pisać? Kto? Kto to niby dostał akademickie bobki za piszczenie, ja czy Ty? Za co Ci dali, za co? Pytam się z goryczą. 
Chciałem dziś po południu napisać list do Panny, ale byłem bardzo śpiący, bo chociaż czuję się bardzo dobrze, ale tej nocy przyszła jakaś dziwna bezsenność i nie mogłem zasnąć zupełnie. Powróciłem do zajęć, o godz. 5-tej i zdrzemnąłem się, a później zamówiłem rozmowę z Tobą telefoniczną, lecz nie można było doczekać się i o godz. 12-ej przez chwilą odwołałem, by Cię czasem nie budzili i nie straszyli po nocy.

A list ten piszę, leżąc wygodnie w łóżeczku, a rano wyślę. [...]

Munduru nie dostałem jeszcze, list polecony z zawartością tak. Bardzo dziękuję za już i za jeszcze, no i pisać jak najwięcej. Chociażby tak dla wprawy, może się jeszcze kiedyś wyrobisz i literatką zostaniesz (Z Tobq 98).

List składa się jedynie $\mathrm{z}$ formuł uobecniania żony i ucieleśniania siebie: poza dopominaniem się o listy i opisem pisania do Lilki oraz relacji z próby kontaktu telefonicznego i podziękowaniu na paczkę - „nic” tu nie ma. Właśnie to „nic” umożliwia i uprawomocnia wszelkie strategie uobecnienia, ucieleśnienia korespondentki, z których korzysta Jasnorzewski. Tym „niczym” jest bowiem kontakt pozakorespondencyjny - lata wspólnego życia i doświadczeń, do których odwołuje się mąż, rozmowy telefoniczne oraz spotkania na żywo, z których „stenopisów” nie uzyskamy i nie poznamy. Ich nieobecność najbardziej uwydatnia relacyjny charakter korespondencji oraz jej silny związek z codziennością i doczesnością, w tym całkowicie zrozumiały brak dbałości o to, by tworzyć kompletny (narracyjnie, faktograficznie, opisowo) obraz znajomości i samej/samego siebie ${ }^{41}$. Idiolektalny język Jasnorzewskich (piszczeć - pisać; akademickie bobki - to Złoty Wawrzyn Akademii Literatury, nagroda, którą poetka otrzymała w 1935 roku) rozkrusza skostniałe formuły kompozycyjne listu i stereotypowe frazy, nie jest jednak językiem wytworzonym na potrzeby korespondencji, ale językiem codzienności pary i ich bliskich.

\section{Zakłócenia fantazji o uobecnieniu: dzwonek telefonu}

Znaczenie korespondencji wytwarza się w relacji obojga korespondentów, ale figury uobecnienia wytwarza się w samotności: fantazjując i pisząc. Akt pisania odbywa się w konkretnym, realnym czasie, choć odwołuje się zarówno do „czasu korespondencji”, przeszłości i przyszłości. Dlatego też przerwanie pisania listu rozmową telefoniczną (szczególnie, gdy rozmówcą jest adresat), wywołuje efekt niesamowitości. Tę skomplikowaną sytuację, w której dwie technologie komunikacji na odległość - telefon i list/karta pocztowa, nakładają się na siebie, wyraził Adam Zagajewski w wierszu List. Oda do wielości:

Twój telefon przerwał mi pisanie listu do ciebie.

Nie przeszkadzaj mi, gdy

$\mathrm{z}$ tobą rozmawiam. Dwie

nieobecności krzyżują się,

jedna miłość rozdziera się

jak bandaż.

\footnotetext{
${ }^{41} \mathrm{Nie}$ jest to oczywiście jedyny model korespondencji. Por. autobiograficzny model listopisania, który na przykładzie Witkacego opisuje Olga Szmidt. Olga Szmidt, Korespondent Witkacy (Kraków: Universitas, 2014).
} 
Tłumaczenie wiersza na sytuację listopisania byłoby mniej więcej takie: dezorientacja lirycznego „ja” wynika z wytrącenia z procesu fikcjonalizacji odbiorczyni i fantazjowania na jej temat - poprzez kontakt pośredni (łącze telefoniczne), ale w czasie rzeczywistym. Wiersz wydobywa paradoks krzyżowania się dwóch nieobecności, czyli dwóch sposobów wytworzenia kontaktu w sytuacji fizycznej absencji. Kiedy jedna zostaje przerwana przez drugą, wywołuje to dysonans poznawczy. Dlaczego oznacza to dla podmiotu lirycznego zagubienie w miłości? To już pole dla interpretacji.

W korespondencji Jasnorzewskich temat rozmów telefonicznych jest rzadkością, co wynikało z warunków wojennych i mieszkalnych pary. Przytoczony list o nieudanej próbie kontaktu należy do wyjątków. U Szymborskiej i Filipowicza to ważny i powracający temat, o czym najlepiej świadczy wyimek z listu Filipowicza:

\footnotetext{
Wymyśliłaś rodzaj emocji, na który jestem (zawsze byłem) szczególnie wrażliwy, ale uważam, że szkoda dla mnie takich wzruszeń - w tym miejscu odezwał się telefon i usłyszałem Twój głos. Był to z całą pewnością Twój głos - ale nagrany na taśmę magnetofonową (zagraniczną oczywiście). Co też ludzie nie wymyślą! Niedługo będzie można odprawiać randki za pomocą telewizji. Ale ja wolę z Tobą konwencjonalnie i bardzo czekam chwili, kiedy to będzie możliwe (Najlepiej 142; kolor zmieniony przez Filipowicza, a później wydawcę).
}

To przypadek, który mógł wprawić pisarza w dużo większą konsternację niż rozmowa telefoniczna: słuchał bowiem nagrania, tj. zapisu dokonanego w innym czasie niż ten, w którym odsłuchiwał wiadomości. Zarazem jednak nie mógł odpowiedzieć na wiadomość: kontakt był tak samo ,jednostronny” i oparty na nieobecności, jak pisanie listu. Dlatego też Filipowicz informację o tym doświadczeniu opisał, używając innego koloru długopisu. Wyjaskrawienie jest konieczne, by wyodrębnić czas, w którym nagranie głosu Szymborskiej „przeszkodziło” pisaniu do niej listu. Z perspektywy kompozycji nie byłoby ono potrzebne. Można przecież zakończyć list, jak gdyby sytuacja nie miała miejsca, a potem ją ewentualnie opisać albo opowiedzieć przy spotkaniu na żywo. Tyle że zbyt silne jest doświadczenie „krzyżowania się nieobecności”, by mogło zostać zignorowane. List Filipowicza odtwarza wypadek niemal w realnym czasie, w którym został wytrącony $\mathrm{z}$ aktu uobecniania i fikcjonalizacji korespondentki.

Zazwyczaj wzmianki o rozmowach telefonicznych nie mają aż tak niesamowitej aury. Najpierw tłumaczą, dlaczego kontakt telefoniczny nie był w pełni udany: przede wszystkim ze względu na brak intymności, np. wtedy gdy Szymborska była we wspólnej sali w sanatorium („Kornelu! Kochany! Nie mogę Ci przez telefon powiedzieć, jak jest smutno i pusto bez Ciebie" (Najlepiej 238]), a Filipowicz miał w domu gości [„Kochana Wisławo! Wybacz, że w czasie naszej ostatniej rozmowy telefonicznej (przed dwoma godzinami) nie powiedziałem Ci nic miłego - ale miałem na głowie St.[anisława] R[óżewicza]" (Najlepiej 269)]. Rozmowa telefoniczna może się nie udać dużo bardziej niż wymiana listów, między innymi dlatego, że nie pozwala na bezgraniczne fantazjowanie i ogranicza fikcjonalizację. Konfrontacja z głosem bywa rozczarowująca albo niepokojąca, jak wynika z listu Szymborskiej do Filipowicza: „Dwie godziny po rozmowie telefonicznej z tobą doszłam do wniosku, że jeszcze muszę troszeczkę pogadać. Choćby dlatego, żebyś mnie potem nie pytał, czemu mój głos był jakiś inny i czy się coś nie zmieniło. A zmienia się tylko to, że coraz bardziej tęsknię!” (Najlepiej 137). Skoro pisanie jest przedłużeniem „pogadania”, to odnosi się do werbalnej komunikacji i sytuacji dialogu, ale jako ich wyobrażenie. Przybiera postać monologu na temat tego, co by było, gdyby korespondenci 
mogli kontynuować przerwaną rozmowę telefoniczną. Wyobrażony i sfikcjonalizowany Filipowicz jest obsadzony w roli adwersarza, na którego potencjalne zarzuty odpowiada Szymborska. Oto język pragnienia typowy dla listu miłosnego ${ }^{42}$. W odpowiedzi na ten właśnie list Filipowicz odpowiada, wskazując na kolejne zaburzenie sytuacji pisania: „W tym miejscu zadzwonił telefon od Ciebie. Miałaś tym razem głos bardzo miły, nie wzbudzający żadnych wątpliwości ani podejrzeń..." (Najlepiej 139). Nie można stwierdzić, czy Filipowicz odsłuchał zapisu głosu, czy rozmawiał z Szymborską. Kolejny list od Szymborskiej dopomina się - z humorem - o wyznania: „Chciałam Cię o to zapytać przez telefon, ale zdecydowałam, że lepiej będzie dostać odpowiedź na piśmie” (Najlepiej 140): tak, jakby pewne sprawy (obok barwy i brzmienia głosu, znamionujących uczucia, także otwarte deklaracje) były możliwe do stematyzowania jedynie za pomocą konkretnego medium, pisma i listu. Choć wydawałoby się, że kontakt telefoniczny jest bardziej bezpośredni od listownego, ponieważ oddalenie fizyczne „niweluje” zwrotność i możliwość swobodnej wymiany zdań, to jednak właściwości głosu, pozbawione kontekstu innych niewerbalnych właściwości „mowy ciała” jak gestykulacja i mimika, w połączeniu z warunkami rozmowy, ale także sama sytuacja „niepełnej” komunikacji sprawiają, że pośredniość multiplikuje się wraz z „krzyżowaniem się nieobecności”.

Pełnię oraz ideał, do którego odwołują się Szymborska i Filipowicz, Pawlikowska-Jasnorzewska i jej mąż, zapewniać miałaby fizyczna obecność interlokutorów. A jednak świadomość bliskości spełnienia tego ideału rzadko powstrzymuje korespondentów przed pisaniem - zwłaszcza pisaniem o pisaniu, pisaniem o telefonowaniu i pisaniem o spotkaniu: „Kochany! Ta karteczka to oczywiście znowu musztarda po obiedzie, bo przyjedzie do Ciebie w poniedziałek, a ja w sobotę pozwolę sobie na przyjemność rozmawiania z Tobą” (Najlepiej 169). „Kornelu! Xiążę! Piszę w sobotę, więc tuż przed niedzielnym telefonem do Ciebie i dlatego nie pytam, co słychać, bo sobie to wcześniej oboje wyjaśnimy" (Najlepiej 189). Tłumaczenie się z pozornie bezzasadnych gestów pisania, pozdrawiania i zadawania pytań jest i paradoksalne, i konieczne. Towarzyszy listopisaniu nieodzownie jako akt ustanawiania sytuacji korespondencyjnej i fikcjonalizacji adresata/ nadawcy. W figurach korespondencyjnego uobecnienia liczy się bowiem sam akt uobecniania, nie performatywny, skierowany nie na działanie i przyszły efekt, ale związany z koniecznym fantazjowaniem o korespondencie i wytwarzaniem chronotopicznego „tu i teraz” osoby piszącej list. Uobecnianie to warunek listopisania, tak jak fizyczna nieobecność korespondentów.

\section{Podsumowanie}

Moim celem było ukazanie trzech fundamentalnych i nierozerwalnie ze sobą związanych aspektów korespondencji/listopisania: 1) materialnej namacalności listów oraz wagi różnego typu załączników: paczek żywnościowych, ubraniowych; kolaży, „wyklejanek” i innego typu współtworzących komunikat oraz medium środków; 2) fikcjonalizacji odbiorcy w „wirtualnej rzeczywistości" dyskursu epistolarnego oraz związanych z tym metaepistolograficznych gier; 3) tekstualnych figur i toposów uobecnienia korespondentów oraz tego, w jaki sposób mogą zostać zakłócone. Punktem wyjścia - i dojścia - było przekonanie o prymacie fantazji o fizycznym kontakcie korespondentów, które generuje wszelkie strategie uobecnień, jest pochodną kluczowej dla korespondencji sytuacji nieobecności, a zarazem warunkiem generowania figur uobecnień - które działają, w specyficznych dla korespondowania, czasie i przestrzeni listopisania.

${ }^{42}$ Roland Barthes, Fragmenty dyskursu miłosnego, tłum. Marek Bieńczyk (Warszawa: Alatheia, 2011), 227. 


\section{Bibliografia}

Barthes, Roland. Fragmenty dyskursu miłosnego. Przetłumaczone przez Marek Bieńczyk. Warszawa: Alatheia, 2011.

Barthes, Roland. Przyjemność tekstu. Przetłumaczone przez Ariadna Lewańska. Warszawa: KR, 1997.

Bobilewicz, Grażyna. „Poszukiwania form komunikacji - sztuka poczty". Studia z Filologii Polskiej i Słowiańskiej 41 (2006): 225-237.

Bossis, Mireille. „Methodological Journeys Through Correspondences”. Przetłumaczone przez Karen McPherson. Yale French Studies nr 71 (1986): 63-75.

Całek, Anita. Nowa teoria listu. Kraków: Księgarnia Akademicka, 2019.

Hejmej, Andrzej. „W kulturze dźwięku. Słuchanie literatury". Teksty Drugie 155, nr 5 (2015): 88-102.

Herbert, Zbigniew i Wisława Szymborska. Jacyś złośliwi bogowie zakpili z nas okrutnie. Korespondencja 1955-1996. Opracował Ryszard Krynicki. Kraków: a5, 2018.

Iłłakowiczówna, Kazimiera. Listy do siostry Barbary Czerwijowskiej z lat 1946-1958. Opracowała Lucyna Marzec. Poznań: Wydawnictwo Biblioteki Publicznej i Centrum Animacji Kultury, 2014.

Japola, Józef. „Między retoryką a «głosem»: Walter J. Ong a problemy komunikacji literackiej”. Pamiętnik Literacki 88, nr 3 (1997): 141-156.

Jasnorzewska z Kossaków, Maria. Listy do przyjaciół i korespondencja z mężem (19281945). Opracował i wydał Kazimierz Olszański. Kraków: Wydawnictwo „Kossakiana”, 1998.

Krasiński, Zygmunt. Listy do Konstantego Gaszyńskiego. Opracował Zbigniew Sudolski. Warszawa: PIW, 1971.

Miller, Joseph Hillis. O literaturze. Przetłumaczył Krzysztof Hoffman. Poznań: Wydawnictwo Naukowe UAM, 2014.

Milne, Esther. Letters, Postcards, Email. Technologies of Presence. New York-London, Routledge, 2010.
Moczarska, Zofia i Kazimierz Moczarski. Życie tak nas głupio rozłacza... Listy więzienne 19461956. Opracowała, wstępem i przypisami opatrzyła Anna Machcewicz. Warszawa: Biblioteka „Więzi”, 2015.

Ong, Walter Jackson. „Autor zawsze fikcjonalizuje odbiorcę”. W Osoba, świadomość, komunikacja. Antologia. Przetłumaczone przez Józef Japola. Warszawa: Wydawnictwa Uniwersytetu Warszawskiego, 2010.

Perec, George. Dwieście czterdzieści dwie pocztówki $w$ prawdziwych kolorach. Przetłumaczone przez Jacek Olczyk. W George Perec. Urodziłem się. Eseje. Przetłumaczone przez Jan Gondowicz, Ewelina Kuniec, Monika Ławniczak, Michał Paweł Markowski, Anna Olczyk, Jacek Olczyk, Tadeusz Pióro, Agata Rębkowska, Ewa Wieleżyńska, Adam Zdrodowski. Redakcja: Jacek Olczyk. Kraków: Wydawnictwo Lokator, 2012.

Rypson, Piotr. Mail art., czyli sztuka poczty. Warszawa: Akademia Ruchu, 1985.

Sikora, Agata. „List”. W Od aforyzmu do zinu. Gatunki twórczości słownej. Zredagowane przez Grzegorz Godlewski, Marta Rakoczy, Paweł Rodak. Warszawa: Wydawnictwa Uniwersytetu Warszawskiego, 2014.

Skwarczyńska, Stefania. Teoria listu. $\mathrm{Na}$ podstawie lwowskiego pierwodruku opracowała Elżbieta Feliksiak. Białystok: Wydawnictwo Uniwersytetu w Białymstoku, 2006.

Szmidt, Olga. Korespondent Witkacy. Kraków: Universitas, 2014.

Szymborska, Wisława i Kornel Filipowicz. Najlepiej w życiu ma Twój kot. Opracował Tomasz Fiałkowski i Sebastian Kudas. Kraków: Znak, 2016.

Z Toba jednym: listy Marii PawlikowskiejJasnorzewskiej i Stefana Jasnorzewskiego. Wybór i opracowanie Elżbieta Hurnikowa. Warszawa: W.A.B., 2015. 


\title{
SEOWA KLUCZOWE:
}

\author{
o b e c n o ść \\ list
}

\section{MARIA PAWLIKOWSKA-JASNORZEWSKA}

\begin{abstract}
AbstrakT:
Artykuł omawia korzyści płynące $\mathrm{z}$ konceptualizacji korespondencji jako medium interpoetyckiego. Analizuje tekstowe i wizualne sposoby uobecniania adresata i nadawcy w listach oraz ich zakłócenia powodowane przerwaniem pisania listu przez rozmowę telefoniczną. Wskazuje na rolę fikcjonalizacji odbiorcy i nadawcy jako warunku wytworzenia „wirtualnej rzeczywistości" listu. Przedstawia podstawowe figury i toposy uobecniania w korespondencji na podstawie zbiorów korespondencji: Wisławy Szymborskiej i Kornela Filipowicza, Marii Pawlikowskiej-Jasnorzewskiej i Stefana Jasnorzewskiego, Stanisława Barańczaka i Lecha Dymarskiego oraz Zofii i Kazimierza Moczarskich.
\end{abstract}


Wisława Szymborska

\section{metaepistemologia}

\section{NOtA O AUTORCE:}

Lucyna Marzec - adiunktka na Wydziale Filologii Polskiej i Klasycznej UAM , redaktorka „Czasu Kultury”, członkini Rady Naukowej Interdyscyplinarnego Centrum Badań Płci Kulturowej UAM. Publikuje artykuły z zakresu biografistyki, krytyki feministycznej i życia literackiego XX wieku; e-mail: lucyna.marzec@amu.edu.pl. 